\title{
Approaches in Forming and Interpreting the Translation of Reading Text in the Diploma Class
}

\author{
Dewanto, Wijaya Putra University Surabaya
}

\begin{abstract}
Translation is the process of transferring one language to another language by changing source language (SL) into target language (TL). Translation is the changing of one language into other language (Webster, 1984). Translation involves a process of language transmitting that turns out to be problematic for students in understanding the meaning of each word. This research is done to know more about the effective approaches in translation for diploma students. The data is taken from diploma students. The data is obtained qualitatively by giving test, recording, and drilling. The purpose of this study is observing students' comprehension in dealing with word sentences approaches and translation meaning of reading text. This research uses two approaches, namely (1) sentence by sentence translation approach and (2) transitional text analysis. Hopefully, those approaches can help the students' understanding of translation.
\end{abstract}

Keywords: approaches; meanings; translation; words

\section{Introduction}

Nowadays, the development of knowledge has changed the way people think or the way researchers conduct research. Most of them commonly has tried and implied the best way of teaching, especially in teaching translation. Translation is the way to transfer from the source language (SL) to the target language (TL). Many translators have implied some effective approaches in teaching their students. Translation is a human activity which even though in some stages machine can also be utilized in the process of translating, yet it is well-known that machine cannot start the process of translating until someone has inputted the necessary data into it (Sorvali, 1996). Furthermore, Bell (1991) stated that translation is replacing a representation of a text of one language with a representation of an equivalent meaningful text in another language.

Translation does not simply define as an easy process of transferring from TL to SL but sometimes it also needs some equipment to complete the result that the writers want. Lately, the fact shows that in the process of translation, translators need the assistance of electronic tools. Even though translators have methods and approaches in translation, the sophistication of technology lately also helps translators in the process of translation. Bassett (2002) stated that the electronic media explosion of the 1990s and its implications for the processes of globalization have highlighted the issues of intercultural communication. He also remarked that translation is not only a monistic composition, but also a conglomeration and interpenetration of two structures. On the one hand, there are semantics content and formal contour of the original text. On the other hand, the entire system of the aesthetic features in the source text bound up with the language of the translation.

The process of translation needs methods and strategies to understand the meanings and the aims of translation. In doing translation, translators need strategies and also approaches to ease the students. An approach is a set of assumption about what the language is and how language learning takes place (Adisutrisno, 2016). In other words, approach is method of doing something to achieve the purposes. Approach can be defined as the process or the ways of dealing with something. Approach is also meant as one of the step, process, and procedure in doing something. The current research uses several approaches, namely (1) sentences by sentence translation and (2) transitional text analysis. Those approaches are supported by lexical meaning, reference and component theories. Those approaches are hoped to help the students in doing translations. The object of this study is the diploma's students of SBC School in Gresik. This research only discusses about the approaches intended to help the students who enroll the translation class. 
In the process of translation, translators, therefore, apply several criteria that transcend the purely linguistics where the process of decoding and recoding take place. Beside the approaches, the translators also understand about the cultures of each language. It is one of the aspects needed by the translators to comprehend culture. Decoding and recoding are also important in translation. Eugene Nida's model of translation process showing the steps of the translation process is illustrated below.

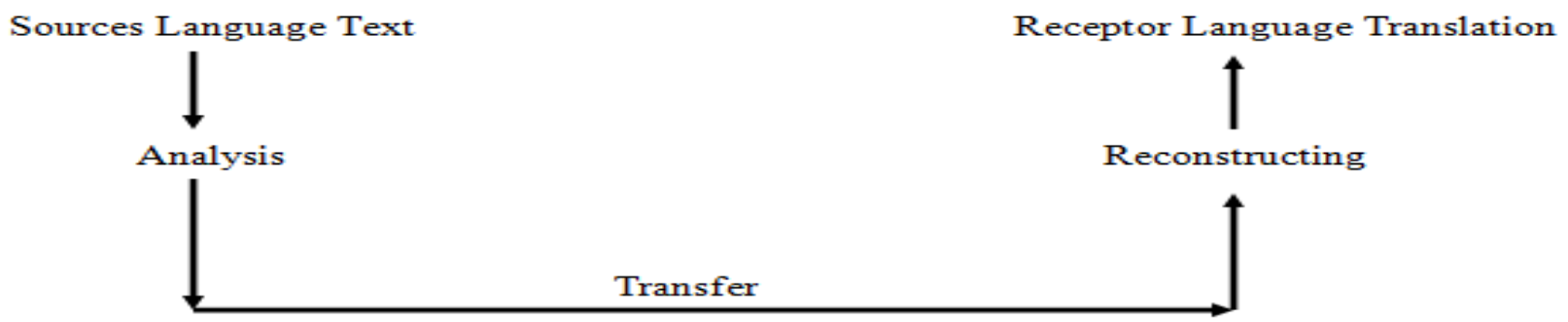

Figure 1. The Process of Decoding and Recoding in Translation (Bassett, 2002)

The problem of translating yes and hello into French, German and Italian is considered as example of some complexities occurred in interlingual translation. However, this research does not discuss those languages. The current study discusses about the approaches in translation.

Translation means transferring the meaning of the sources language into the receptor language. In the process of translation, only the forms change (Larson, 1998). The forms of language refer to the actual words, phrases, clauses, sentences, paragraph, and so on which are found either in spoken or in written. Larson (1998) gave the description of translation process as shown in the following figure.

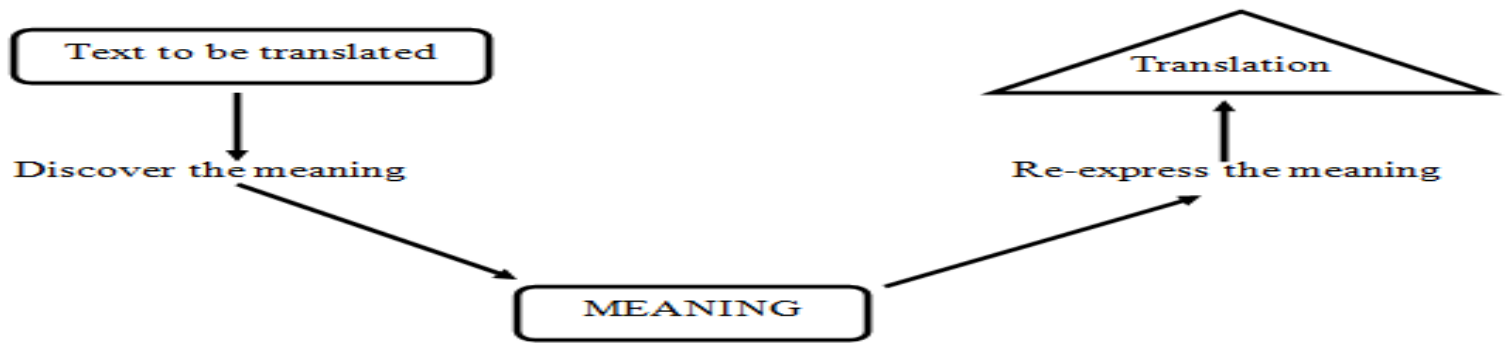

Figure 2. The Process of Translation (Larson, 1998: 4)

From the figure above, Larson (1998) explained that translation involved the study of the lexicon, the grammatical structure, the communication situation and cultural context of the source language text. Translators should firstly analyze the elements previously mentioned in order to determine its meaning. Then, the translators should reconstruct the same meaning using the appropriate lexicon and grammatical structure of the receptor language and its cultural context. Additionally, in this article the above translation process is used in the learning or translation for beginners.

\section{Research method}

This research uses method that attempted to find the suitable approaches for forming and interpreting the translation of reading text. In analyzing the data, the present research utilizes qualitative approach. Research is activity consist of steps that will be done every year (Mahsun, 2005: 73). This research was also done step by step that needed more time to conduct deep research. This research focuses on the approaches in translation that used by the students in the class. The data collection uses documentation technique, and the data analysis uses qualitative method. 


\section{Finding and discussion}

Translating means reproducing the closest natural equivalent messages of the source language in the receptor language, in term of meaning and style (Nida, 1974).

\subsection{Types of translation}

Translation is the process of transferring SL into TL. It needs comprehension about the translation. Roman Jacobson on his article 'On Linguistic Aspects of Translation' distinguishes three types of translation:

(a) Intralingual translation or rewording (an interpretation of verbal signs by means of other signs in the same language).

(b) Interlingual translation or translator proper (an interpretation of verbal signs by means of some other language).

(c) Intersemiotic translation or transmutation (an interpretation of the verbal signs by means of sign of nonverbal sign systems).

\subsection{Procedure of translation}

Translation procedures involve translation, transliteration, borrowing, literal, transposition, modulation, and adaptation. Newmark (1998: 81) pinpointed that translation procedures comprise methods applied by translators when they formulate the equivalent translation of the elements of meaning transferred from SL to TL. The following are methods of translation proposed by Newmark (1998: 81).

(a) Word-for-word translation that translates every single word by word without considering the context.

(b) Literal translation that includes the conversion of SL grammatical constructions to their closest TL equivalent.

(c) Faithful translation that attempts to produce precise contextual meaning of the original structure within the constraints of the target language structure.

(d) Semantics translation that can be clearly seen if the source language text contains many cultural term.

(e) Adaptation that is considered the freest of translation.

(f) Free translation that creates the translated version of texts without the style, form, or content of the original text.

(g) Idiomatic translation that translates phrases from the other language based on the culture.

(h) Communicative translation that aims to transfer the precise contextual meaning of the original text in such a way. It is done to make both content and language acceptable and comprehensible to the readership.

\subsection{Conceptual meaning}

In forming and meaning process of translating texts, the translation of word sentences cannot be avoided from the meaning. Meaning is one of the approaches in translation. Bell (1999) proposed that conceptual meaning sometimes called as 'denotative meaning' or 'cognitive meaning' is widely assumed to be the central factor in verbal communication. In addition, Conceptual meaning are integral to the essential function of language in a way that other types of meaning are not much found in the dictionary.

\subsubsection{Conceptual text}

The data of this research are in the form of text. This research focuses on the sentence by sentence approach of forming and interpreting the text. Text has many types, such as legal, administrative, dialect, local, cultural. Translation attempts to transfer as many SL words as possible to the TL words. A text may therefore be pulled in ten difference directions as follows:

(a) The individual style or idiolect of the SL.

(b) The conventional grammatical and lexical usage ofa type of text that depends on the topic and the situation

(c) Content items that specifically refer to the SL or third language culture (for example not SL or TL).

(d) The typical format of a text in a book, periodical, newspaper, and so onthat is influenced by the tradition of a certain time. 
(e) The expectation of the putative readership, bearing in mind that their estimated knowledge of the topic and the style of the language they use expressed in term of the language common factors, should not be translated down (or up) to the readership.

(f) (7), (8) as for (2), (3) and (4) respectively, but related to the TL.

(g) Something that is being described or reported, ascertained or verified (the referential truth), which is possible to meet the independence of the SL text and the expectation of the readership.

(h) The views and prejudices of translators, which might be personal and subjective or sometimes social and cultural, involve the translators' group loyalty factor, which may reflect the national, political, ethnic, religious, social class, and sex assumptions of the translators.

\section{The term of the fact of the matter}

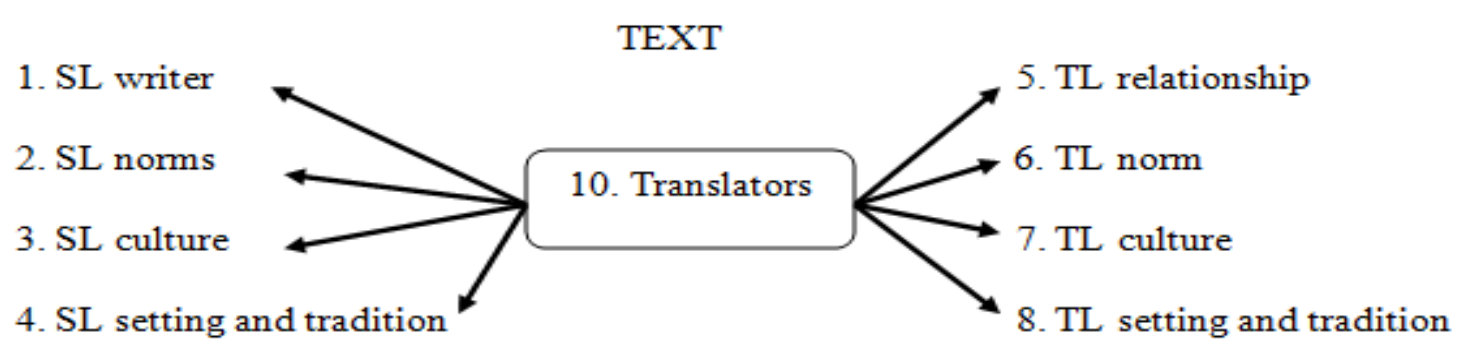

Figure 3.Dynamic Translation of Text (Newmark. 2002)

\subsection{The approaches of translation}

According to Newmark (1988), translation needs process. He added that the process of translation needs the relation of translating to translation theory, the approach, the textual level, the referential level, the cohesive level, the unit of translating, the translation of text and the translation of proper names.

There are two approaches of translation. First is starting to translate sentence by sentence, then moving to the first paragraph or chapter, to get the feel and the tone of the text and then you deliberately sit back, review the position, and read the rest of the SL text. Second is reading the whole text two or three times, to find the intention, the register, the tone, and to mark the difficult words and passages before translating.

\subsection{Reference theory}

The theory that investigates of the interaction of language with words is called theory of reference. This theory divides the semantic content of every expression into two components: sense and meaning ("denotation", "nominate" and "reference", among others).

\subsection{Componential analysis}

Componential analysis which is also called as feature analysis or contrast analysis refers to the description of the meaning of words through structured sets of semantic features, which are given as "present", "absent" or "indifferent with reference to feature".

\subsection{Meaning postulate}

Reading text is one of the object data ofthe current research. This research focuses only on the word and sentences of reading text.

\section{Discussion}

This research uses approaches that appropriate for students in diploma's class. Of course, there the students in senior high school are different to university and diploma's class. The analysis of meaning and structural forms of both source languages and target languages are based on the principles of translation proposed by Nida (1975). The principles concern about adding, mitigating, and skewing information. Additionally, theory proposed by Catford (in Venuti, 2000) that includes the level shift and category shift in translation is also used to analyze the data. 
Translation is the result of illustrating text from sources language to target language utilizing several appropriate theories and approaches. Translation is divided into three distinctive types.

(a) Full and partial translation. In partial translation, some parts of the SL text are left untranslated.

(b) Total and restricted translation. In restricted translation, the level of language is involved.

(c) Rank translation. In this level, the grammatical hierarchy of translation equivalent is established.

This research found some data from the result of students' test. Below is the data for this research.

\begin{tabular}{|l|l|l|}
\hline Sources Language (SL) 1 & Meaning \\
\hline She likes hamburger & Target Language (TL) & $\begin{array}{l}\text { The TLstill uses the native } \\
\text { language. It has meaning to } \\
\text { indicate the word like. }\end{array}$ \\
\hline
\end{tabular}

In data 1 ,a simple sentence is presented 'she likes hamburger'. Mostly the students use sentenceby-sentence approach. It is recognized from the percentage of the result in the translation test. The result shows the percentage that reaches $80 \%$. Thestudents make efforts to use strange word (borrowing word) to translate the word 'hamburger' because the TL (Indonesia) still does not have the term to translate the word 'hamburger'.

Data 2

\begin{tabular}{|l|l|l|}
\hline Sources Language (SL) & Target Language (TL) & Meaning \\
\hline The man intended to here & Orang itu hendak kesini & $\begin{array}{l}\text { The translator considers that } \\
\text { the word 'intended' has the } \\
\text { similar meaning with } \\
\text { 'wanted'. }\end{array}$ \\
\hline
\end{tabular}

Based on the data 2 above, the sentence shows that the translator wants to define the word 'intended' to show the purpose. This translation process involves transition text analysis. It can be analyzed from the sentences. The word 'the man' is considered as the subject, while'intended' as the verb, which then is followed by 'here' that is seen as the adverb of place. The students translate the word 'intended' to 'wish' or 'want'. But the result shows the percentage that is less than $5 \%$. So it can be concluded that the students still use the transitional analysis approach.

Data 3

\begin{tabular}{|l|l|l|}
\hline Sources Language (SL) & Target Language (TL) & Meaning \\
\hline $\begin{array}{l}\text { Big cat-like pumas are found in } \\
\text { America }\end{array}$ & $\begin{array}{l}\text { Macan tutul seperti kucing yang } \\
\text { besar ditemukan di Negara } \\
\text { Amerika. }\end{array}$ & $\begin{array}{l}\text { The translator finds this } \\
\text { sentence complex, so 'puma' } \\
\text { is translated as 'macan tutul' }\end{array}$ \\
\hline
\end{tabular}

In this data, the students try to translate word to word but the students translated the identified subject of the sentence as the description of animalthat is compared to cat. Data 3 refers to the second approach in which the students use the similar translation to compare puma with cat.

Data 4

\begin{tabular}{|l|l|l|}
\hline Sources Language (SL) & Target Language (TL) & Meaning \\
\hline $\begin{array}{l}\text { Our vicar always wants money } \\
\text { as the reason or the other }\end{array}$ & $\begin{array}{l}\text { Pendeta kami selalu ingin uang } \\
\text { sebagai satu alasan atau yang } \\
\text { lainnnya }\end{array}$ & $\begin{array}{l}\text { Both approaches are used in } \\
\text { translating this sentence. The } \\
\text { translators encounter } \\
\text { difficulties. Sometimes they } \\
\text { need to combine transition } \\
\text { analysis approach with the } \\
\text { other approach. }\end{array}$ \\
\hline
\end{tabular}

In this data, the subject is one. However, the subject also can be referred or represented as the relative pronoun 'he'. Thus, in translating the data, double approaches are used, namely sentence-by- 
sentence and transitional text analysis approach. It is due to the complex sentence that makes the students translate the sentence word-by-word.

\section{Conclusion}

Based on the analysis, the result of this translation research above can be concluded that the appropriate approach for the diploma students is transitional text analysis. It does not mean that the students do not like to use the sentence-by-sentence approach. However, the students prefer to translate word to word or phrase to phrase or common called as transitional text analysis. It is identified from the fewer mistakes when using transitional text analysis approach in the translation test.

\section{References}

Adisutrisno, W. 2016. The language approach to writing teaching material through the world. TEFLIN. Surabaya: Proceeding TEFLIN. p. 302-309.

Bassnett, S. 2002. Translation studies. London and New York: Routledge.

Bell, R. T. 1991. Translation and translating, theory and practice. London and New York: Longman Inc. Catford. I. C. 1965. A linguistic theory of translation. London: Oxford University Press.

Dewanto. 2016. Methods, strategy and problems in translation for the beginners. TEFLIN. Surabaya: Proceeding TEFLIN 2016.P. 302-309.

Mahsun. 2005. Metode penelitian bahasa. Jakarta: Rajawali Pers.

Newmark, P. 1988. A textbook of translation. New York: Prentice. Hall

Rachmadie, Sabrony. 1999. Translation. Jakarta: Universitas Terbuka.

Sorvali, I. 1996. Translation studies in a new perspective. Frankrut: Peter Lang. 